\title{
Enclosure, Land Improvement, and the Price of Capital
}

\author{
A Reply to Jones \\ Gregory ClarK \\ Department of Economics, University of Michigan
}

\section{INTRODUCTION}

In "The Cost of Capital and Medieval Agricultural Technique" I argued that the enclosure movement, and potentially also much of the increase in yields per acre in British agriculture up to 1850 , could be explained by a fall in the rate of return on capital from 1400 to 1800 , which induced substantial investment in land improvement (Clark, 1988). Eric Jones counters that enclosures and yield increases occurred on a large scale only in the 17th century, a good 200 to 300 years after the first significant decline in rates of return circa 1400 (Jones, 1990). Further, the general land improvements I identified as potentially explaining the yield increases only affected the physical properties of the soil, while the major constraint on yields was the lack of organic material in the soil.

I accept that the absence of much enclosure from 1400 to 1600 and the failure of yields to rise before 1600 is prima facie evidence against the argument of my paper. But I think that a simple modification of the account to incorporate the other elements in the cost of capital will provide an explanation that is reasonably consistent with the timing of agricultural improvements. And I think we can use the cost of capital to explain the absence of manuring in the medieval period also.

\section{ENCLOSURE, LAND IMPROVEMENTS, AND CROP YIELDS}

Consider first the specific issue of the influence of capital costs on the enclosure movement. Suppose, as in Clark (1988) that there was a fixed benefit per acre of $B$ gained from enclosure, where $B$ is measured in terms of agricultural output. The cost of enclosing per acre was $p_{\mathrm{K}} C /(A)^{1 / 2}$, where $A$ is the area of field enclosed and $p_{\mathrm{K}}$ is the price of 
TABLE 1

Cost of Capital: 1200 to 1850

\begin{tabular}{lcccc}
\hline & $\begin{array}{c}w / p \\
\text { Years }\end{array}$ & $\begin{array}{c}w / p \\
(\%)\end{array}$ & $\begin{array}{c}w / p \\
(\text { craftsmen }) \\
(1300=100)\end{array}$ & $\begin{array}{c}\text { Cost of capital } \\
(r \cdot w / p) \\
(1300=100)\end{array}$ \\
\hline $1200-1250$ & 10.3 & - & - & $-100)$ \\
$1250-1300$ & 10.2 & 98 & 94 & 95 \\
$1300-1349$ & 10.6 & 100 & 100 & 100 \\
$1350-1399$ & 7.0 & 141 & 129 & 93 \\
$1400-1449$ & 5.6 & 170 & 171 & 91 \\
$1450-1499$ & 5.6 & 167 & 178 & 88 \\
$1500-1549$ & 5.5 & 152 & 123 & 63 \\
$1550-1599$ & 5.9 & 114 & 90 & 51 \\
$1600-1649$ & 6.0 & 89 & 66 & 52 \\
$1650-1699$ & 5.4 & 101 & 80 & 56 \\
$1700-1749$ & 4.3 & 137 & 112 & 42 \\
$1750-1799$ & 3.7 & 119 & 101 & 50 \\
$1800-1849$ & 3.8 & 137 & 121 & \\
\hline
\end{tabular}

Sources. Rate of return (Clark, 1988, Table 3, p. 273). Agricultural prices and real wages of craftsmen (Phelps-Brown and Hopkins, 1981, pp. 44-57). Threshing payments per bushe! (Clark, 1991).

Note. The rate of return is the weighted average of the rates of return on rent charges and on land holding for these years reported in Clark (1988), modified as described in the text.

fencing, since the fencing required per acre falls as $A$ rises. Enclosure would be profitable only if

$$
p \cdot B \geqslant(r+\delta) \cdot p_{\mathrm{K}} C /(A)^{1 / 2},
$$

where $r$ is rate of return on capital, $\delta$ is the depreciation rate, and $p$ is the price of output. With this specification there would always be some minimum size of field which could be profitably enclosed, $A^{*}$, where

$$
A^{*}=(C / B)^{2}\left(p_{\mathrm{K}} / p\right)^{2}(r+\delta)^{2} .
$$

In my paper $I$ assumed for convenience that agriculture capital never depreciated so that $\delta=0$ and $p_{\mathrm{K}}=p$. In this case

$$
A^{*}=(C / B)^{2} \cdot r^{2} \text {. }
$$

If $C / B$ was constant over time, $A^{*}$ would thus depend on $r^{2}$, the square of the rate of return on capital. Table 1 shows $r$ for 50-year periods from 1200 to $1850 .{ }^{1}$ Figure 1 shows the associated minimum enclosure size

${ }^{1} r$ is the weighted average of rates of return on rent charges and land reported in Clark (1988, Table 3, p. 273). The rate for 1450-1500 has been set to the average of the rates for 1400-1450 and 1500-1550, since there are only 3 observations for this period and 29 observations for the adjacent periods. 


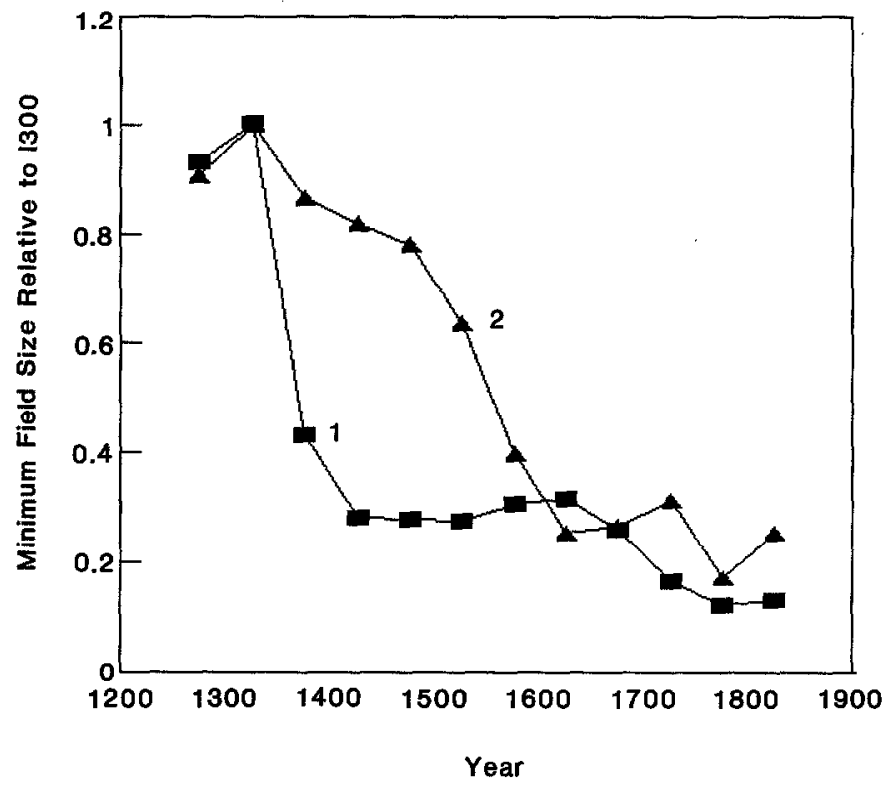

FIG. 1. Minimum field size for profitable enclosure, 1250-1850. Series $1(\square)$ is the minimum field size required to make enclosure profitable if the cost of capital relative to output is $r$. Series $2(\boldsymbol{A})$ is the minimum field size if the cost of capital is $r \cdot(w / p)$.

relative to the minimum size in $1750-1800$. Since I calculated the minimum size in the late 18th century at between 3 and 4 acres, this implies minimum field sizes until 1400 that were larger than the typical farm. But clearly the minimum field size fell sharply by 1450 , long before there was large-scale enclosure.

The assumption that $p_{\mathrm{K}}=p$ is the probable source of the gap between the fall in the required minimum field size and the enclosure movement. For $p_{\mathrm{K}}$ to equal $p$, agricultural output and capital have to be produced using the same proportions of land, labor, and capital. But many land improvements-draining, fencing, clearing stones, marling, and so onwere much more labor intensive than the production of agricultural output. At the extreme, suppose agricultural capital was composed purely of labor inputs. In this case

$$
p_{\mathrm{K}}=a \cdot w,
$$

where $w$ is the wage. The minimum field size would now be

$$
A^{*}=(a C / B)^{2}(w / p)^{2} r^{2},
$$

where $r \cdot w / p$ is the cost of capital. Table 1 shows two possible series for $w / p$. The first is the day wage of building craftsmen in the south of 
England. The second is the payment per bushel for threshing and winnowing wheat. The two series are quite similar. Series 2 in Fig. 1 shows the minimum field size for profitable enclosure on the assumption that $p_{\mathrm{K}}=a \cdot w$, measuring wages in agriculture by the threshing cost. According to it, the minimum field size did not fall greatly until the late 16 th century. This fits reasonably with the known chronology of the enclosure movement. Wordie argued recently, indeed, that the 17 th century was the great period of enclosure (Wordie, 1983). This would be consistent with my revised estimate of the cost of capital.

Jones also argued that while I assume that investments such as fencing and soil improvements were infinitely lived, in fact they depreciated fairly quickly, making them less interest sensitive than I assumed. If in fact a certain fraction of the investment has to be spent each year to keep the fences, walls, and ditches in repair, then the minimum field size will be a function of the square of the cost of capital, now

$$
(r+\delta)^{2}(w / p)^{2}
$$

As $\delta$ becomes bigger relative to $r$, the cost of capital will vary more with $w / p$ and less with $r$ itself. There is, however, little reason to believe that $\delta$ was large for walls and hedges. Hedges did require periodic maintenance, but the cost per year was only about $1 \%$ of the initial cost. Hedges also yielded valuable fuel that probably more than covered the labor of trimming them and of scouring the associated ditches. Thus it seems reasonable to assume that the overall maintenance cost of fencing was generally close to 0 .

I speculated that increased investment in land improvement could have explained much more than just the $10 \%$ or so increase in yields we associate with enclosure. We can apply the argument above to explain why this investment need not have occurred until the 17 th century even though the rate of return on capital fell significantly around 1400 . The last column of Table 1 shows the cost of capital from 1250 to 1850 if capital goods were composed entirely of labor.

A further complication here is that yields depended both on the amount of capital invested in land improvement and on the amount of direct labor put into the crop. High real wages from 1350 to 1600 would both increase the direct costs of capital and lead to fewer direct labor inputs into crops. Only in 1600-1650, when both capital costs and real wages were lower than in the high medieval period $1250-1350$, should we necessarily observe higher yields per acre. The timing of the predicted rise in yields per acre and the actual increase is thus much closer than Jones would suggest. I do concede, however, that the evidence for significant yield improvements in the course of the 17 th century is not strong. 


\section{THE RATE OF RETURN AND THE POSTAN THESIS}

The cost of capital could also greatly affect yields by influencing the stock of organic material farmers maintained in the soil. ${ }^{2}$ Postan argued that medieval grain yields were low and declining because too large a share of the land was arable. There was thus insufficient manure generated by pasture land for the arable that became exhausted of nutrients vital to crop growth, in this period most likely nitrogen (Postan, 1972, pp. 57-72; Chorley, 1981, pp. 71-94; Shiel, 1991). But why would medieval cultivators cultivate so much arable if this greatly reduced grain yields? They certainly knew the value of manure.

The high cost of capital in the medieval period provides an alternative economic underpinning to the Postan thesis. The amount of mineral nitrogen available to aid crop growth depends on the stock of organic nitrogen in the soil, which in the long run depends mainly on the input of nitrogen compounds from nitrogen fixation by leguminous plants in pasture and by pulses grown on the arable. ${ }^{3}$ Uncultivated land builds up a large stock of organic nitrogen and, if ploughed, will initially give good grain yields. But without a compensating inflow from manure or from rotating land between pasture and arable, eventually the stock of organic nitrogen on arable land falls to low levels. The amount of nitrogen it paid to keep in stock in the soil, and hence the crop yields, would be heavily influenced by the rate of return on capital.

To illustrate this, consider the following simplified description of the decision the cultivator had to make about what proportion of the land to keep arable. Suppose there were only two inputs in producing agricultural output, land and capital. Let $M=k N$ be the mineral nitrogen available per acre of arable, where $N$ is the stock of organic nitrogen in the soil of arable land, and $k$ is the rate at which it breaks down into mineral nitrogen. ${ }^{4}$ Suppose the yield of grain per acre was $M$ bushels unless $M>M^{*}$, when the yield would be $M^{*}{ }^{5}$ An additional unit of nitrogen added to the soil by manure would thus create a series of yield increases in future years as the organic nitrogen broke down into mineral nitrogen. The present value of this stream of yield increases, and the implicit value to the farmer of a unit of nitrogen, in bushels of grain,

${ }^{2}$ This thought was stimulated by reading Shiel's description of the role of nitrogen in crop growth. Shiel (1991).

${ }^{3}$ Free-living bacteria in the soil may fix some nitrogen.

${ }^{4}$ In reality there are several types of organic nitrogen in the soil, each with different decay rates (Shiel, 1991). But this does not materially influence the analysis that follows.

${ }^{s}$ It has been argued that extra mineral nitrogen available to crops at medieval yield levels would have increased yields by a constant amount per unit to some threshold level (Chorley, 1981; Shiel, 1991). 
would be

$$
p_{\mathrm{m}}=k /(1+r)+k(1-k) /(1+r)^{2}+\cdots=k /(r+k),
$$

where $r$ is the rate of return on capital.

Let the output of arable that is never manured be $A$ bushels of grain per year, which would be the rental value of arable land. Let the value of pasture products be the equivalent of $V$ bushels of grain per acre ( $A$ $>V$, and let the nitrogen produced for the arable per acre of pasture be $S .^{6}$ Then the cost of producing a unit of nitrogen in manure is

$$
c=(A-V) / S \text {. }
$$

Farmers will only find it worthwhile to keep land in pasture and apply manure to the arable if $p_{\mathrm{m}}>c$, or

$$
\begin{aligned}
k /(r+k) & >(A-V) / S \\
r & <k(V+S-A) /(A-V) .
\end{aligned}
$$

Once the rate of return on capital falls low enough, all the arable will be manured up to the point where the yield is $M^{*}$; otherwise no manure is applied and most of the land is kept as arable. If, for example, $k$ was $0.05, A$ was 10 bushels of grain per year, $V$ was the equivalent of 5 bushels of grain, and $S$ was 10, then the threshold value of $r$ below which manuring would be profitable would be $5 \%$. The intuitive explanation is that any medieval cultivator who sought higher yields would have to switch a large proportion of his land to pasture, which would diminish current income since yields would not immediately rise by very much.

Another way of generating nitrogen that was more efficient, since much of the nitrogen produced on permanent grassland did not get transferred to the arable, was to rotate land between grain and a nitrogen-fixing crop. Suppose the land spends a fraction $z$ of the time in the rotation growing grains. Then the value of manure to the farmer will now be approximately,

$$
p_{\mathrm{m}}=z \cdot k /(r+k)
$$

since it only produces output for a fraction $z$ of years. The cost of not growing grain on a piece of land and instead growing the nitrogen-fixing crop, per unit of extra nitrogen generated is

$$
c=(k N-V) /(S-A)
$$

if we assume that nitrogen mineralizes at a constant rate $k N$ and that the input of nitrogen with a grain crop is $A$, while with a nitrogen-fixing

\footnotetext{
${ }^{6}$ I assume for simplicity here that the stock of nitrogen in the pasture land soil does not change.
} 
crop it is $S>A$. For the level of nitrogen in the soil to be stable over time we must have the input equal the output, or

$$
\begin{aligned}
z \cdot A+(1-z) S & =k N \\
z & =(S-k N) /(S-A) .
\end{aligned}
$$

To maximize profits the farmer should increase $N$ until the value of extra nitrogen just equals the cost, or

$$
\begin{aligned}
z \cdot k /(r+k) & =(k N-V) /(S-A) \\
N & =[V+S+r V / k] /(r+2 k) .
\end{aligned}
$$

$d N / \mathrm{d} r$ is negative as long as $S>V$, which follows from the assumption that $S>A>V$. If $S$ is much larger than $V$ then $r$ will have a big effect on the level of $N$. For example, if $V$ is 0 , then $N-S /(r+2 k)$.

The above models are schematic but they do illustrate how the cost of capital may have had even more extensive effects on the choice of technique in medieval agriculture than were argued for in my original article. $^{\text {? }}$

\section{REFERENCES}

Chorley, G. P. H. (1981), "The Agricultural Revolution in Northern Europe, 1750-1880: Nitrogen, Legumes and Crop Production." Economic History Review 34(1), 71-94.

Clark, Gregory (1988), "The Cost of Capital and Medieval Agricultural Technique." Explorations in Economic History 25, 265-294.

Clark, Gregory (1991), "Labor Productivity in English Agriculture 1300-1860." In Bruce Campbell and Mark Overton (Eds.), Historical Studies of Productivity Change in Agricultural Development. Manchester: Manchester Univ. Press. Forthcoming.

Jones, Eric (1990), "Enclosure, Land Improvement, and the Price of Capital: A Comment." Explorations in Economic History 27, 350-355.

Phelps-Brown, Henry, and Hopkins, Sheila V. (1981), A Perspective of Wages and Prices. London: Methuen.

Postan, M. M. (1972), The Medieval Economy and Society. London: Weidenfeld \& Nicolson.

Shiel, Robert S. (1991), "Improving Soil Productivity in the Pre-fertilizer Era." In Bruce Campbell and Mark Overton (Eds.), Historical Siudies of Productivity Change in Agricultural Development. Manchester: Manchester Univ. Press. Forthcoming.

Wordie, J. R. (1983), “The Chronology of English Enclosure, 1500-1914." Economic History Review 36(4), 483-505.

${ }^{7}$ This story about the rate of return controlling the stock of nitrogen in the soil and hence crop yields is open to Jones's objection that yields did not begin to increase until long after the decline in rates of return. But manuring land was often a labor-intensive operation. With permanent pasture, for example, stock had to be fed indoors with feed cut from the pasture and the manure then taken out to the field and mixed with the topsoil. In this case the profitability of manuring to increase yields depends both on the rate of return and on the real wage. 